University of Nebraska - Lincoln DigitalCommons@University of Nebraska - Lincoln

Transactions of the Nebraska Academy of Sciences and Affiliated Societies

Nebraska Academy of Sciences

Spring 5-7-2018

\title{
Potential Minimum Threshold for Pallid Sturgeon Relative Condition in the Lower Missouri River
}

Kirk D. Steffensen

Nebraska Game and Parks Commission, kirk.steffensen@nebraska.gov

Follow this and additional works at: https://digitalcommons.unl.edu/tnas

Part of the Aquaculture and Fisheries Commons

Steffensen, Kirk D., "Potential Minimum Threshold for Pallid Sturgeon Relative Condition in the Lower Missouri River" (2018).

Transactions of the Nebraska Academy of Sciences and Affiliated Societies. 515.

https://digitalcommons.unl.edu/tnas/515

This Article is brought to you for free and open access by the Nebraska Academy of Sciences at DigitalCommons@University of Nebraska - Lincoln. It has been accepted for inclusion in Transactions of the Nebraska Academy of Sciences and Affiliated Societies by an authorized administrator of

DigitalCommons@University of Nebraska - Lincoln. 


\title{
Potential Minimum Threshold for Pallid Sturgeon Relative Condition in the Lower Missouri River
}

\author{
Kirk D. Steffensen \\ Nebraska Game and Parks Commission, Fisheries Division, 2200 North 33 ${ }^{\text {rd }}$ Street, Lincoln, Nebraska 68503. \\ email kirk.steffensen@nebraska.gov; tel. 402.471.1514
}

\begin{abstract}
Pallid Sturgeon (Scaphirhynchus albus) condition has declined in the lower Missouri River but the cause and the effects of this decline remain uncertain. Adult Pallid Sturgeon are becoming reproductively ready less frequently and sub-adult Pallid Sturgeon are likely delaying sexual maturation. Even more concerning, Pallid Sturgeon capture rates have declined the past two years (i.e., 2016 and 2017), despite the ongoing Pallid Sturgeon stocking program. Several Pallid Sturgeon that have been captured are visually emaciated but a minimum condition threshold has not been described. Therefore, the aim of this study is to present a potential lethal condition level for adult Pallid Sturgeon in the lower Missouri River then determine the capture frequency of Pallid Sturgeon below this assumed minimum condition threshold to test the validity of this hypothesis. Based on the mortality of an individual female adult Pallid Sturgeon held in captivity, mortality occurred when condition was 0.71 . This potential minimum threshold is further supported with very few adult Pallid Sturgeon captured below this predicted minimum threshold. Using the minimum condition threshold established here to continue monitoring the Pallid Sturgeon population and the occurrence of individuals below this condition level could help managers better address factors hindering Pallid Sturgeon recovery.
\end{abstract}

Keywords: endangered species, Missouri River, recovery, condition, Scaphirhynchus, sturgeon

doi: $10.13014 / K 2 S F 2 T D R$

\section{Introduction}

Understanding the effects of a decline in fish condition is not well understood but likely affects growth, maturation, reproductive frequency, fecundity and ultimately survival (Pope and Kruse 2007). Karr (1981) suggested that reduced growth rates, recruitment, and condition are generally indicators of poor environmental quality. Recent observations and analyses have shown a decline in Pallid Sturgeon (Scaphirhynchus albus) condition in the upper channelized reach of the lower Missouri River (Steffensen and Mestl 2016, Steffensen et al. 2017a, Randall et al. 2017). This decline appears to be restricted to the reach from Gavins Point Dam (rkm 1305.1) downstream to the Kansas River confluence ( $\mathrm{rkm}$ 591.4). The cause of this decline remains unknown as several factors including discharge, intraspecific competition, interspecific competition (e.g., Shovelnose Sturgeon [Scaphirhynchus platorynchus] and Flathead Catfish [Pylodictis olivaris]) and food availability were not significantly correlated with declining condition (Steffensen and Mestl 2016, Randall et al. 2017). However, the severe flooding conditions on the Missouri River in 2011 is hypothesized as a contributing factor as abiotic factors, such as channel degradation and incision (Alexander et al. 2013), likely negatively affected riverine habitats, prey availability and intra- and interspecific competition.

Prior to the 2011 Missouri River flood, the remnant wild-origin Pallid Sturgeon population appeared stable, despite limited documented reproduction and recruitment (Steffensen et al. In Review), while the hatchery-origin population in the lower Missouri River was increasing due to the Supplementation Program. Hatchery-reared Pallid Sturgeon were surviving (Steffensen $e t$ al. 2010, Steffensen et al. 2016), growing (Shuman et al. 2011, Hamel et al. 2014), and spawning (DeLonay et al. 2009, DeLonay et al. 2010, DeLonay et al. 2012) with the sturgeon population in good condition (Shuman et al. 2011, Steffensen et al. 2014a). While the stocking rates followed an approved plan, minimum stocking objectives were not achieved (USFWS 2008); however, there were no indications that population levels (i.e., intraspecific competition) might be impacting condition.

As the condition of the Pallid Sturgeon population declined after the 2011 flood, fewer Pallid Sturgeon in reproductive condition were captured. Steffensen and Mestl (2016) hypothesized the poor condition recently observed has caused Pallid Sturgeon to limit the frequency of becoming reproductively ready and possibly delay sexual maturation. More concerning, Pallid Sturgeon capture 
rates and population estimates have declined, despite the ongoing Supplementation Program (Steffensen et al. 2017b), which may indicate increased mortality rates or higher rates of emigration from the lower Missouri River. However, evidence of increased emigration is lacking as Pallid Sturgeon capture frequencies are not increasing in other reaches of the lower Missouri River (K. Steffensen, unpublished data). Therefore, the objective of this study is to (1) present a novel mortality record of an adult Pallid Sturgeon as a potential threshold of critical minimum condition before mortality then (2) use Pallid Sturgeon capture data from the Nebraska Game and Parks Commission (NGPC) to determine the capture frequency of Pallid Sturgeon below this assumed minimum condition threshold.

\section{Materials and Methods}

\section{Study site}

The study area was the upper channelized reach of the lower Missouri River, specifically the reach immediately below the Missouri and Platte rivers confluence (rkm 957.6), along the eastern Nebraska border to the Nebraska-Kansas state line (rkm 788.4). This section of the Missouri River has been highly engineered and channelized with an approximate $200-\mathrm{m}$ wide incised river channel.

\section{Capture information}

Since 2003, NGPC has been a participating agency in the Pallid Sturgeon Population Assessment Program (PSPAP), which is the main Pallid Sturgeon monitoring program on the Missouri River which monitors the relative abundance of benthic fish species with a suite of gears (Welker and Drobish 2016, Welker et al. 2016). Additionally in early-April 2008 through 2017, NGPC has conducted an intensive sampling effort to collect adult Pallid Sturgeon for the lower Missouri River Supplementation Program (Steffensen et al. 2017b). These reproductively ready adult fish are transferred and spawned at hatchery facilities to provide progeny to supplement the Pallid Sturgeon population.

Fish \#470426226D (hereinafter, 226D) was originally captured on 16-April-2015 and transferred to the Missouri Department of Conservation's Blind Pony State Fish Hatchery (BPSFH, Sweet Springs, MO) as a potential broodfish. Fish 226D was transferred to the U.S. Fish and Wildlife Service's Neosho National Fish Hatchery (NNFH, Neosho, MO) to hold until fish 226D could attain reproductively readiness and contribute to the Supplementation Program. Capturing reproductively ready fish from the wild has become increasingly difficult the past several years (K. Steffensen, unpublished data) so potential broodfish, that are not reproductively ready when captured, were held over in hatcheries to be spawned the following years after condition improves and fish can put energy into gonad development.

\section{Hatchery environment}

At NNFH, fish 226D along with several other wild-origin adult Pallid Sturgeon that were captured in the lower Missouri River were held in a $7.3 \mathrm{~m} \times 1.8 \mathrm{~m} \times 0.61 \mathrm{~m}$ raceway with a total volume of $6,116 \mathrm{~L}$ with a flow rate of $56.8 \mathrm{~L} /$ minute at a constant $16.6^{\circ} \mathrm{C}$ until they become reproductively ready. Tank density was 4 fish per tank and fish were fed approximately 50 (total length $50-100 \mathrm{~mm}$ ) Rainbow Trout Oncorhynchus mykiss weekly but individual prey consumption was not monitored. Routine water chemistry analysis showed no abnormal levels of heavy or light metals, pesticides, PCBs or herbicides.

\section{Condition and models}

To measure how condition varied while being held at $\mathrm{NNFH}$ and to compare the relative condition of the other Pallid Sturgeon captured by NGPC, the Shuman et al. (2011) equation was used to calculate relative condition (Kn). All broodfish held at NNFH, including fish 226D, were periodically weighed but fork length was not recorded. Length data were only recorded at initial capture and after death so when growth became asymptotic was unknown. Therefore, to estimate the change in condition, growth (i.e., length) was modeled under two scenarios: (1) continual, linear daily growth from initial capture to death and (2) asymptotic growth which assumed that daily growth was also linear but peaked simultaneously with the maximum observed weight then length ceased and remained constant until the time of death.

\section{Recapture frequency}

To determine if initial capture condition affected the likelihood of an individual being recaptured, a chisquared analysis was conducted on the capture-recaptured data from NGPC's database. Pallid Sturgeon were grouped based on the initial $\mathrm{Kn}$, to the nearest 0.01 , then the expected recapture probabilities were compared to the observed recapture probability using SAS 9.4 $(\alpha=0.05)$.

\section{Results}

At initial capture, fish 226D was $905 \mathrm{~mm}$ (fork length) and weighed $2660 \mathrm{~g}$, which resulted in a relative condition $(\mathrm{Kn})$ of 0.87 and determined to be a non-reproductive female at BPSFH. After two weeks, fish 226D was transferred to NNFH and held for 662 days until death 
occurred. During that time, fish 226D appeared to be feeding normally and grew a total of $90 \mathrm{~mm}$. Weight initially increased by $260 \mathrm{~g}$ during the first 217 days in captivity but declined thereafter. Under the continual growth model, condition rapidly increased to 0.95 but then steadily declined until mortality occurred where Kn was determined to be 0.71 (Figure 1). Under the asymptotic growth model, fish 226D displayed a steady decline in $\mathrm{Kn}$ during the first year in captivity after which Kn remained static until mortality occurred.

A total of 671 individual adult sized $(>800-\mathrm{mm})$ Pallid Sturgeon have been captured since NGPC began sampling Pallid Sturgeon under the PSPAP protocols, totaling 933 capture events when accounting for recaptures. Only 14 adult Pallid Sturgeon were captured with an initial Kn less than 0.71 (Figure 2) and those fish have never been subsequently recaptured. However, no statistical difference was detected for the likelihood of being recaptured based on initial capture condition $\left(x^{2}=27.15\right.$, $\mathrm{p}=0.9988)$.

To visualize changes in condition, a series of pictures of Pallid Sturgeon which are all approximately 1000-mm fork length are presented (Figure 3). Relative condition values varied from 0.70 to 1.10 with a stepwise change of 0.10 which is roughly equivalent to a $400 \mathrm{~g}$ difference in weight for a $1000-\mathrm{mm}$ size fish.

\section{Discussion}

Individual fish are likely tolerant to different minimum conditions but this unique circumstance provides a general baseline assessment for when relative condition may be lethal for Pallid Sturgeon but this baseline may likely depend on age, gender and reproductive stage. Although

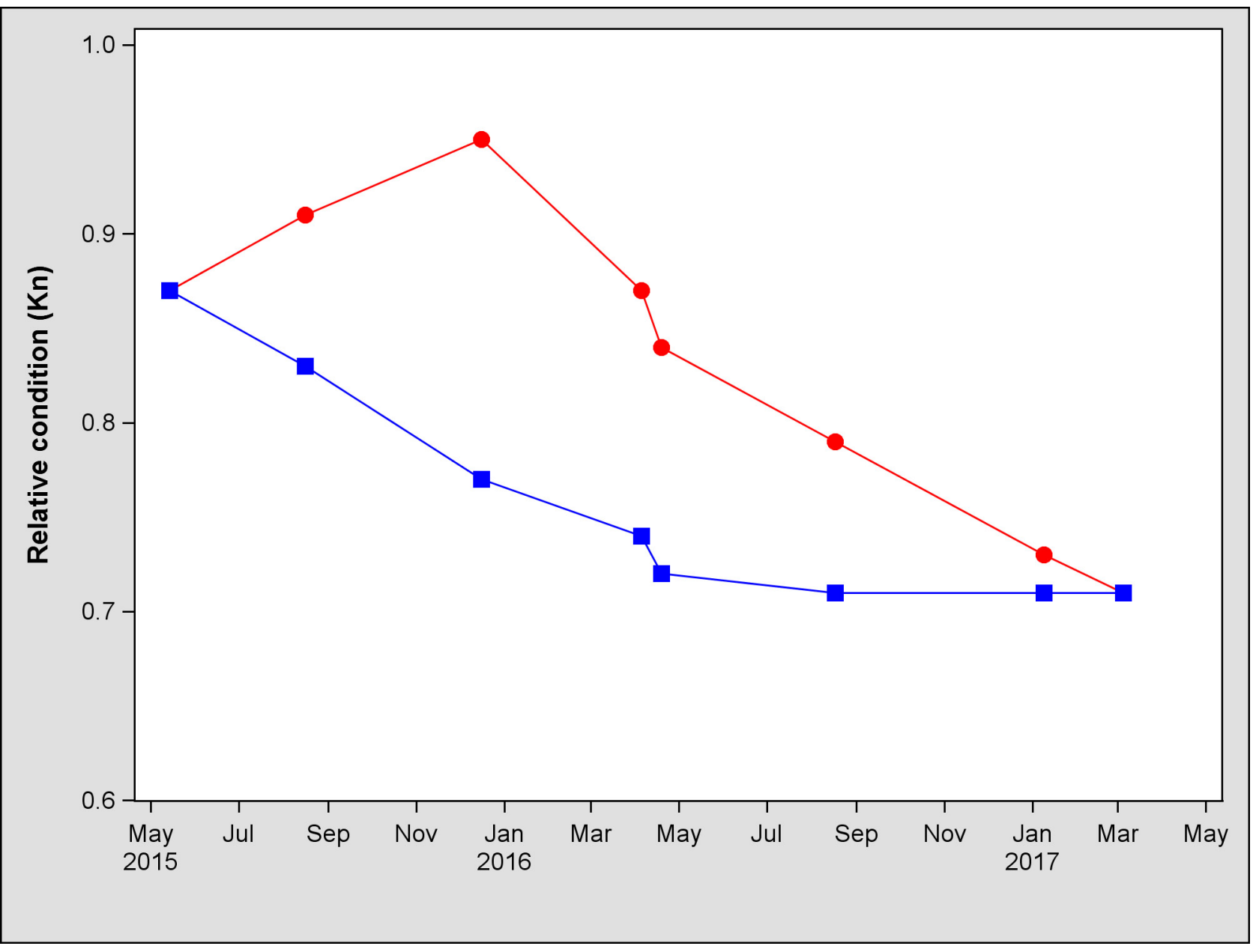

Figure 1. Modeled relative condition (Kn) for female Pallid Sturgeon \#470426226D. The red circles represent continual growth from initial capture to death while the blue squares represent asymptotic growth that length and weight simultaneously peaked then length was maintained at length observed at time of death. 


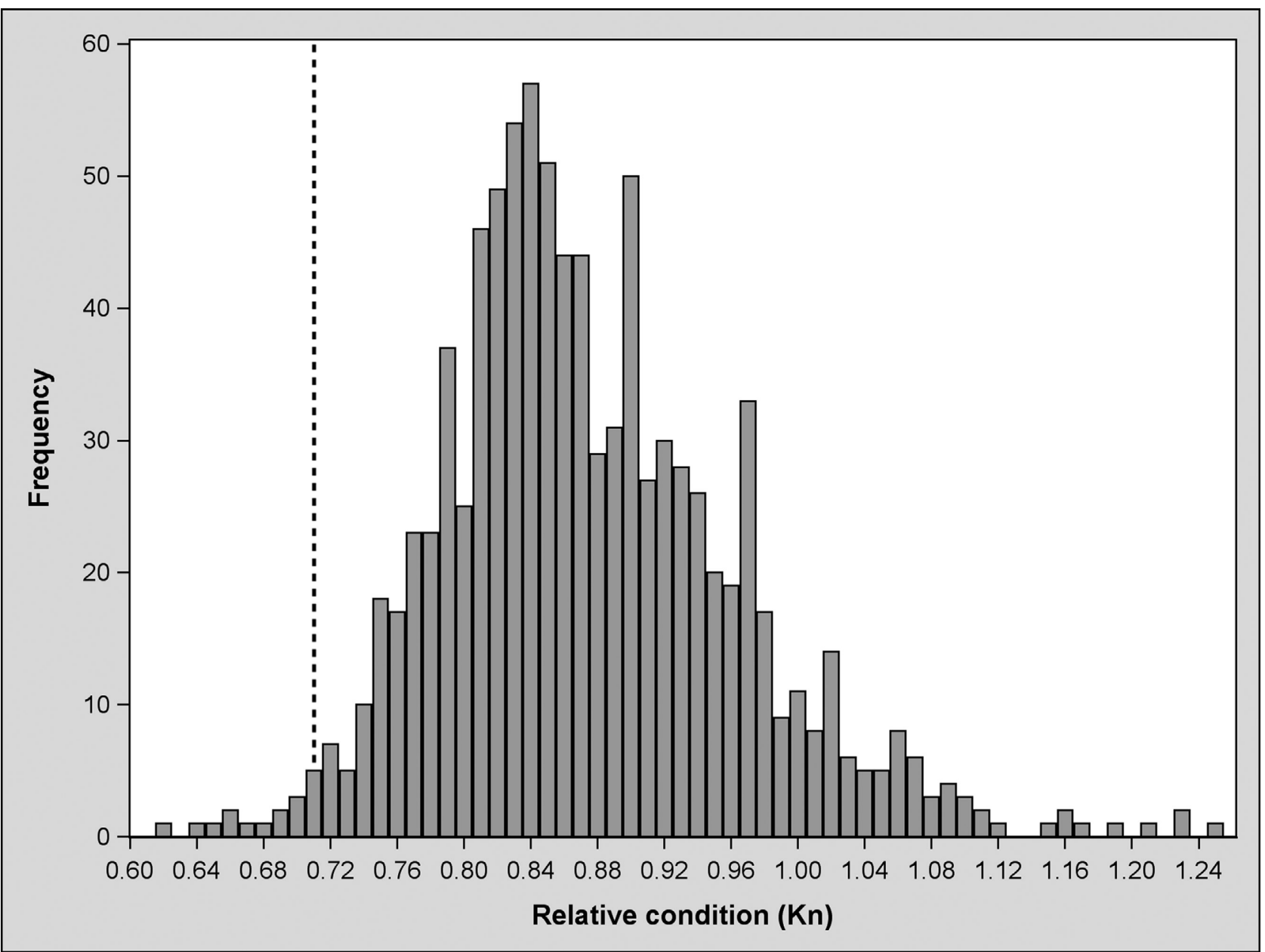

Figure 2. Relative condition (Kn) distribution of adult sized ( $\geq 800-\mathrm{mm}$ ) Pallid Sturgeon captured by Nebraska Game and Parks Commission from the upper reach of the lower Missouri River from 2003-2016. Vertical dashed line indicates potential minimum threshold for Pallid Sturgeon relative condition.

this baseline should be interpreted cautiously outside the lower Missouri River as it is acknowledged this is based on a single observation but this was the first and only observed occurrence of an adult Pallid Sturgeon mortality in the lower Missouri River. The PSPAP data shows probable support for this relative baseline, as very few Pallid Sturgeon have been collected in a similar condition to fish 226D at the time of death. Based on observations in the field, Pallid Sturgeon with a Kn of less than 0.80 appear visibly "skinny". Since natural reproduction and the development of a naturally self-sustaining population is the main recovery objective for Pallid Sturgeon, understanding the impacts of low condition on Pallid Sturgeon growth, maturation, reproductive cycling, and survival is critical to recovery efforts in the lower Missouri River. Steffensen and Mestl (2016) previously reported that decreased condition in adult Pallid Sturgeon appears to be affecting the maturation rate, likely decreasing fecundity and interrupting reproductive cycling. Even if a female can achieve reproductive readiness, Quist et al. (2004) noted that female Pallid Sturgeon in poor condition could result in lower survival and growth of their offspring; however, follow-up research pertaining to this assumption is lacking.

At initial capture, fish 226D relative condition $(\mathrm{Kn}=$ 0.87 ) was one of the higher $\mathrm{Kn}$ values observed in adults during the 2015 sampling efforts and was greater than the observed adult $(\geq 800-\mathrm{mm})$ mean $(0.82 \pm 0.07)$. Being a female and above average condition determined why fish 226D was selected to hold-over as a potential broodfish for the Supplementation Program. Generally, wild-origin Pallid Sturgeon rapidly gains weight after being transferred to a hatchery. Fish 226D initially gained weight but not as rapidly as the other Pallid Sturgeon held in captivity (R. May, Neosho National Fish Hatchery Manager, Pers. Comm.) but did not display any deleterious effects 


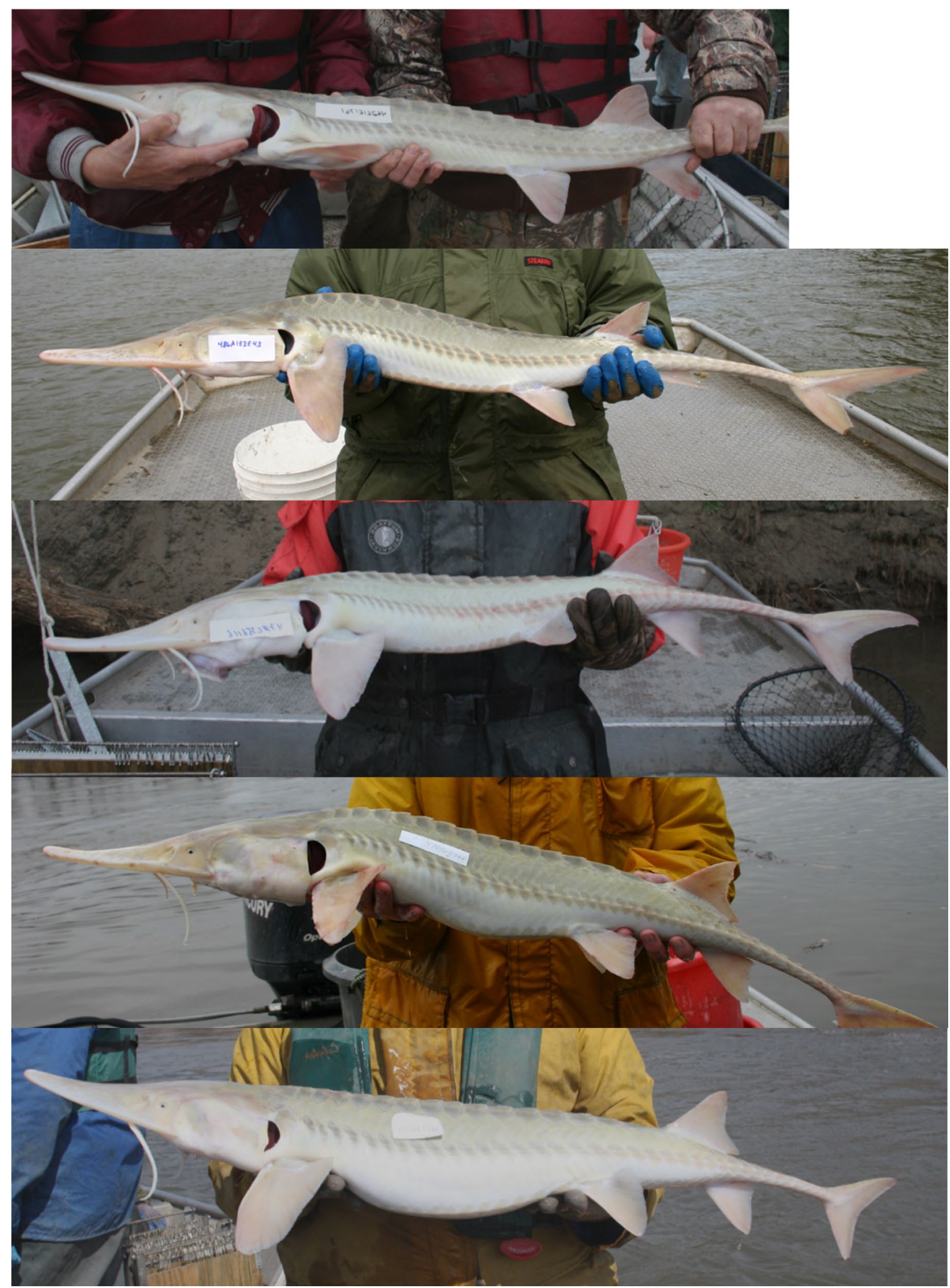

Figure 3. Examples of the visual differences in relative condition for a 1000-mm adult Pallid Sturgeon. Pallid Sturgeon relative condition is incremental from 0.70 (top image) to 1.10 (bottom image) by 0.10 , which equates to approximately $400 \mathrm{~g}$. 
until the last few months. A fish health assessment was not completed after death as fish 226D had no apparent health issues and disease was determined unlikely as it was being held in the same tank as several other adult Pallid Sturgeon.

The targeted condition value for Pallid Sturgeon in the lower Missouri River has not been documented or completely understood, but Quist et al. (1998) recommended 80-90 for the sympatric Shovelnose Sturgeon Scaphirhynchus platorynchus. This recommendation appears to align for the general, non-reproductively ready Pallid Sturgeon population. However, male Pallid Sturgeon likely need to attain a relative condition of approximately 0.90 while female Pallid Sturgeon need to attain a Kn of approximately 0.97 to become reproductively ready (Steffensen and Mestl 2016). Fortin et al. (1996) speculated that higher condition in Lake Sturgeon Acipenser fulvescens increased spawning frequency and likely fecundity but similar data are lacking for the rarer Pallid Sturgeon.

This assessment provides a novel record of the approximate minimum condition a Pallid Sturgeon can tolerate prior to being lethal; however, in rare cases, a few fish were observed below this threshold. Until the lower Missouri River can provide the necessary food resources and habitat conditions to maintain adequate condition and allow adult Pallid Sturgeon to become reproductively ready, holding over and reconditioning adult fish in hatcheries may be necessary as an interim measure to prevent mortalities and the loss of potentially critical genetics by ensuring genetic contributions from these fish. Hatchery related mortalities of Pallid Sturgeon have been uncommon; therefore, it is assumed that fish 226D mortality was not associated with being held in a hatchery environment with other adult Pallid Sturgeon or lack of food. I recommend that hatchery managers need to maintain detailed records (i.e., length and weight recorded at regular intervals) of individual fish condition and response to declining health or stress issues. Furthermore, continual monitoring of the adult Pallid Sturgeon population in the lower Missouri River is needed to understand how condition affects reproductive status and survival.

Acknowledgments - Thanks to the staff of the Nebraska Game and Parks Commission Missouri River Program, the Missouri Department of Conservation's Blind Pony State Fish Hatchery and the US Fish and Wildlife Service's Neosho National Fish Hatchery for assisting with the field work, transfer and holding of Pallid Sturgeon in captivity. Also, thank you to Gerald Mestl, Dr. Mark Pegg and the anonymous journal reviewers for providing comments on earlier versions of this manuscript.

\section{References}

Alexander JS, Jacobson RB, and Rus DL. (2013) Sediment transport and deposition in the Lower Missouri River during the 2011 flood. US Geological Survey, Columbia, MO.

DeLonay AJ, Jacobson RB, Papoulias DM, Simpkins DG, Wildhaber ML, Reuter JM, Bonnot TW, Chojnacki KA, Korschgen CE, Mestl GE, and Mac MJ. (2009) Ecological requirements for pallid sturgeon reproduction and recruitment in the Lower Missouri River: A research synthesis 2005-08. US Geological Survey, Columbia, MO.

DeLonay AJ, Jacobson RB, Papoulias DM, Wildhaber ML, Chojnacki KA, Pherigo EK, Bergthold CL, and Mestl GE. (2010) Ecological requirements for pallid sturgeon reproduction and recruitment in the Lower Missouri River: Annual report 2009. US Geological Survey, Columbia, MO.

DeLonay AJ, Jacobson RB, Papoulias DM, Wildhaber ML, Chojnacki KA, Pherigo EK, Haas JD, and Mestl GE. (2012) Ecological Requirements for Pallid Sturgeon Reproduction and Recruitment in the lower Missouri River: Annual report 2010. US Geological Survey, Columbia, MO.

Fortin R, Dumont P, and Guenette S. (1996) Determination of growth and body condition of lake sturgeon (Acipenser fulvescens). Canadian Journal of Fisheries and Aquatic Sciences 53:1150-1156.

Hamel MJ, Koch JD, Steffensen KD, Pegg MA., Hammen JJ, and Rugg ML. (2014) Using mark-recapture information to validate and assess age and growth of long-lived fish species. Canadian Journal of Fisheries and Aquatic Sciences 71:559-566.

Huenemann TW. (2017) Central lowlands and interior highlands pallid sturgeon spawning and stocking summary. Nebraska Game and Parks Commission, Lincoln, NE.

Karr JR. (1981) Assessment of biotic integrity using fish communities. Fisheries 6:21-27.

Pope KL and Kruse CG. (2007) Condition. In CS Guy and ML Brown (Editors) Analysis and interpretation of freshwater fisheries data, pp 423-472. American Fisheries Society, Bethesda, MD.

Quist MC, Guy CS, and Braaten PJ. (1998) Standard weight (Ws) equation and length categories for shovelnose sturgeon. North American Journal of Fisheries Management 18:992-997.

Quist MC, Boelter AM, Lovato JM, Korfanta NM, Bergman HL, Latka DC, Korschgen C, Galat DL, Krentz S, Oetker M, Olson M, Scott CM, and Berkley J. (2004) Research and assessment needs for pallid sturgeon recovery in the Missouri River. University of Wyoming-Laramie, Laramie, WY.

Randall MT, Colvin ME, Steffensen KD, Welker TL, Pierce LL, and Jacobson RB. (2017) Assessment of adult pallid sturgeon fish condition, lower Missouri River - Application of new information to the Missouri River Recovery Program. US Geological Survey, Columbia, MO. 
Shuman DA, Klumb RA, Wilson RH, Jaeger ME, Haddix T, Gardner WM, Doyle WJ, Horner, PT, Ruggles M, Steffensen KD, Stukel S, and Wanner GA. (2011) Pallid sturgeon size structure, condition and growth in the Missouri River basin. Journal of Applied Ichthyology 27:269-281.

Steffensen KD, Powell LA, and Koch JD. (2010) Assessment of hatchery-reared pallid sturgeon survival in the lower Missouri River. North American Journal of Fisheries Management 30:671-678.

Steffensen KD, Shuman DA, Klumb RA, and Stukel S. (2014a) The status of fishes in the Missouri River, Nebraska: pallid sturgeon (Scaphirhynchus albus). Transaction of the Nebraska Academy of Science 34:3-15.

Steffensen KD, Eder BL, and Pegg MA. (2014) Fish community response to floodplain inundation in a regulated river. Journal of Freshwater Ecology 29:413-427.

Steffensen KD and Mestl GE. (2016). Assessment of pallid sturgeon relative condition in the upper channelized Missouri River. Journal of Freshwater Ecology 31:583-595.

Steffensen KD, Powell LA, Stukel SM, Winders KR, and Doyle WJ. 2016. Updated assessment of hatchery-reared pallid sturgeon (Forbes and Richardson, 1905) survival in the Lower Missouri River. Journal of Applied Ichthyology 32:3-10.
Steffensen KD, Mestl GE and Phelps QE. (2017a) Range-wide assessment of pallid sturgeon Scaphirhynchus albus (Forbes and Richardson, 1905) relative condition. Journal of Applied Ichthyology 33:13-21.

Steffensen KD, Powell LA, and Pegg MA. (2017b) Using the robust design framework and relative abundance to predict the population size of pallid sturgeon Scaphirhynchus albus in the lower Missouri River. Journal of Fish Biology 91:1378-1391.

US Fish and Wildlife Service. (1990) Endangered and threatened wildlife and plants; determinations of endangered status for the pallid sturgeon. Federal Registry 55:36641-36647.

US Fish and Wildlife Service. (2008) Pallid sturgeon (Scaphirhynchus albus) range-wide stocking and augmentation plan. US Fish and Wildlife Service, Denver, CO.

US Fish and Wildlife Service. (2014) Revised recovery plan for the pallid sturgeon Scaphirhynchus albus. US Fish and Wildlife Service, Billings, MT.

Welker TL, Drobish MR, and Williams GA. (2016) Pallid sturgeon population assessment project, volume 1.8. US Army Corps of Engineers, Yankton, SD.

Welker TL and Drobish MR. (2016) Missouri River standard operating procedures for fish sampling and data collection, volume 1.8. US Army Corps of Engineers, Yankton, SD. 